\title{
Enhancement of root architecture and nitrate transporter gene expression improves plant growth and nitrogen uptake under long-term low-nitrogen stress in barley (Hordeum vulgare L.) seedlings
}

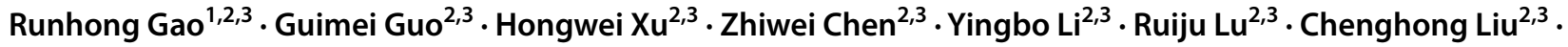 \\ Jianmin Chen ${ }^{1}$ (1)
}

Received: 27 January 2021 / Accepted: 20 August 2021 / Published online: 28 August 2021

(C) The Author(s) 2021

\begin{abstract}
Over application of nitrogen $(\mathrm{N})$ fertilizers to crops ultimately causes $\mathrm{N}$ pollution in the ecosphere. Studying the response of plant growth and $\mathrm{N}$ uptake to low- $\mathrm{N}$ stress may aid in elucidating the mechanism of low $\mathrm{N}$ tolerance in plants and developing crop cultivars with high nitrogen use efficiency (NUE). In this study, a high-NUE mutant line A9-29 and the wild-type barley cultivar Hua30 were subjected to hydroponic culture with high and low $\mathrm{N}$ supply, and the dry weight, $\mathrm{N}$ accumulation, root morphology, and expression levels of the potential genes involved in nitrate uptake and assimilation were measured at seedling stage. The results showed that under low-N conditions, A9-29 had a higher dry weight, $\mathrm{N}$ content, $\mathrm{N}$ influx rate and larger root uptake area than did Hua30. Under long-term low-N stress, compared with Hua30, A9-29 demonstrated higher expression of the HvNRT2/3 genes, especially HvNRT2.1, HvNRT2.5, and HvNRT3.3. Similarly, the expression levels of N assimilation genes including $H v N I A 1, H v N I R 1, H v G S 1 \_1, H v G S 1 \_3$, and $H v G L U 2$ increased significantly in A9-29. Taken together, our results suggested that the larger root area and the upregulation of nitrate transporter and assimilation genes may contribute to stronger $\mathrm{N}$ uptake capacity for plant growth and $\mathrm{N}$ accumulation in responding to long-term low- $\mathrm{N}$ stress. These findings may aid in understanding the mechanism of low $\mathrm{N}$ tolerance and developing barley cultivars with high-NUE.
\end{abstract}

Keywords Barley (Hordeum vulgare L.) $\cdot$ Low-nitrogen stress $\cdot$ Root morphology $\cdot$ Nitrogen influx rate $\cdot$ Nitrate transporter $\cdot$ Nitrogen assimilation

\section{Background}

Communicated by Guoping zhang.

Chenghong Liu

liuchenghong@saas.sh.cn

$\triangle$ Jianmin Chen

jmchen@yzu.edu.cn

1 Jiangsu Key Laboratories of Crop Genetics and Physiology and Plant Functional Genomics of the Ministry of Education, Co-Innovation Center for Modern Production Technology of Grain Crops of Jiangsu Province, Yangzhou University, 225009 Yangzhou, China

2 Biotechnology Research Institute, Shanghai Academy of Agricultural Sciences, 201106 Shanghai, China

3 Shanghai Key Laboratory of Agricultural Genetics and Breeding, 201106 Shanghai, China
Nitrogen $(\mathrm{N})$ is an essential element for plant growth and development, which is fixed into numerous enzymatic proteins and plays a vital role in various biological processes such as photosynthesis (Islam 2019). For agriculture, $\mathrm{N}$ fertilization can significantly increase crop production. Therefore, $\mathrm{N}$ fertilizer are applied in large amounts to achieve maximum crop productivity. However, only $33 \%$ of the total $\mathrm{N}$ applied is present in the harvested grain (Raun and Johnson 1999). The high level of $\mathrm{N}$ input in agriculture causes environmental problems and adds to the financial burden of farmers (Gojon 2017; Sinha et al. 2020). Improving nitrogen use efficiency (NUE) or increasing low N (LN) tolerance in crops to minimize adverse effects and reduce over-dependency on $\mathrm{N}$ fertilizers is important (Chen et al. 2018). 
NUE is a complex trait comprising two physiological components: $\mathrm{N}$ uptake efficiency (NUpE) and $\mathrm{N}$ utilization efficiency (NUtE) (Moll et al. 1982; Xu et al. 2012). The root is the main organ of $\mathrm{N}$ uptake, and root architecture often determines the plant ability to capture N (Iqbal et al. 2020; Jiang et al. 2017). $\mathrm{N}$ shows a remarkable regulatory effect on the development of the root system, and $\mathrm{LN}$ promotes root system growth (Duan 2019; Guo et al. 2017). Therefore, the investigation of root system development is vital for understanding plant responses to $\mathrm{LN}$ stress.

Nitrate is the predominant form of $\mathrm{N}$ available in cereal crops (Miller et al. 2007). The nitrate uptake system consists of the low-affinity transport system (LATS) and high-affinity transport system (HATS) (Fan et al. 2017). NRT2s and the partner proteins NRT3s-also named NAR2-belong to the HATS, which play important roles under limited N conditions (Fan et al. 2017; Li et al. 2017; O'Brien et al. 2016). The expression of some NRT2s increases with the reductions in $\mathrm{N}$ availability - consistent with the increases in nitrate uptake capacity (Plett et al. 2018). Moreover, the transcript levels of NRT2s showed distinct correlations with nitrate uptake capacity and $\mathrm{N}$ availability during maize's lifecycle (Garnett et al. 2013). Among seven NRT2 genes in Arabidopsis, AtNRT2.1, AtNRT2.2, AtNRT2.4, and AtNRT2.5 are expressed in the roots of N-deprived plants (Kiba and Krapp 2016). In Arabidopsis, the interplay between these genes is required for the adaptation to $\mathrm{N}$ limitation (Lezhneva et al. 2014). In rice, three of the $O S N R T 2$ members (OsNRT2.1, OsNRT2.2, and OsNRT2.3a) with OsNAR2.1 are involved in root acquisition of nitrate (Fan et al. 2017; Yan et al. 2011). Ten putative NRT2 genes and three putative NRT3 genes have been bioinformatically identified in barley (Hordeum vulgare L.), all of which are induced in the roots under different $\mathrm{N}$ levels (Guo et al. 2020). At present, three very similar barley NAR2 genes (HvNAR2.1-HvNAR2.3) (Tong et al. 2005), two Arabidopsis NAR2 genes (AtNAR2.1 and AtNAR2.2) (Orsel et al. 2006), and two rice NAR2 genes (OsNAR2.1 and OsNAR2.2) (Yan et al. 2011) have been characterized. However, only one of these is essential for nitrate HATS, such as HvNAR2.3 in barley, OsNAR2.1 in rice, and AtNAR2.1 in Arabidopsis (Feng et al. 2011a; Orsel et al. 2006; Tong et al. 2005; Yan et al. 2011).

After absorption by plants, nitrate is first reduced to nitrite by nitrate reductase (NR) and then further reduced to ammonium by nitrite reductase (NiR). Subsequently, ammonium is assimilated into amino acids by the glutamine synthetase (GS)/glutamine-2-oxoglutarate aminotransferase (GOGAT) cycle (Xu et al. 2012; Criado et al. 2017). NR - the first enzyme involved in plant $\mathrm{N}$ assimilation-has a root architecture remodeling function (Fu et al. 2020). NiR - a central role in N metabolism-is involved in nitrite detoxification and NR activity and senescence regulation (Davenport et al. 2015). The expression of GS isogenes is affected by $\mathrm{N}$ form and availability (Goodall et al. 2013; Thomsen et al. 2014), and the increase in total GS activity under low nitrate is mainly due to GS1 activity (Avila-Ospina et al. 2015). The GS/GOGAT cycle is considered the major pathway for ammonium assimilation in plants. These $\mathrm{N}$ assimilation genes are crucial in plant $\mathrm{N}$ metabolism regulation.

Barley-the fourth major cereal crops worldwide-is used for malt and feedstock production and human consumption globally (Beatty et al. 2010). It has recently become an important model species for Triticeae genomics because it has a simple simple genome (diploid) and an integrated genome database (Han et al. 2016; International Barley Genome Sequencing et al. 2012). Extensive physiological information on $\mathrm{N}$ uptake and transport in barley has been acquired (Chen et al. 2018; Han et al. 2016; Quan et al. 2016). In our previous work, the barley double haploid lines with high-NUE were generated via microspore mutagenesis combined with field screening at anthesis and maturity under LN condition (Gao et al. 2018). These homogenous lines with the genetic background similar to the wild-type Hua30 represent excellent materials to investigate $\mathrm{N}$ uptake and utilization. In the present work, the high-NUE mutant line A9-29 and wild-type Hua30 at the seedling stage were studied, including shoot and root dry weight, $\mathrm{N}$ content, $\mathrm{N}$ influx rate, root morphology, high-affinity nitrate transporter and nitrogen assimilation genes expression.

\section{Materials and methods}

\section{Plant materials and greenhouse experiment}

Hua30 is one of the main barley varieties in Yangtze River Delta in China. A9-29, derived from Hua30 by microspore mutagenesis, has been characterized as a high-NUE line under LN treatment (Gao et al. 2018). Hua30 and A9-29 seeds were surface-sterilized in $75 \%$ ethanol for $1 \mathrm{~min}$, rinsed several times, soaked in distilled water for $6-8 \mathrm{~h}$, and then, placed on moist filter paper in culture dishes in a growth chamber. After $5 \mathrm{~d}$, seedlings with uniform growth were removed seeds and cultured in water for $2 \mathrm{~d}$ and then, transferred into a plastic container $(52 \times 35 \times 15 \mathrm{~cm}$ in length $\times$ width $\times$ height) containing $10 \mathrm{~L}$ of nutrient solution-as described in Chen et al. (2018) with some modifications. $\mathrm{NH}_{4} \mathrm{NO}_{3}$ were supplied at two concentrations: $2.5 \mathrm{mM}(\mathrm{HN})$ and $0.1 \mathrm{mM}(\mathrm{LN})$.

All plants were cultivated in a glasshouse with a 16-h day at $20^{\circ} \mathrm{C} \pm 2{ }^{\circ} \mathrm{C}$. The treatment was conducted at 10:00 $\mathrm{am}$. The roots were collected at 1, 3, 7, 14 and $21 \mathrm{~d}$ of LN treatment, frozen in liquid $\mathrm{N}$, and stored at $-80{ }^{\circ} \mathrm{C}$ for RNA extraction. 


\section{Measurement of dry weight and total N}

The Hua30 and A9-29 seedlings were cultured in $\mathrm{HN}$ and LN nutrient solution for 21d. Samples were collected every $7 \mathrm{~d}$. The shoots and roots were separated and heated at $105{ }^{\circ} \mathrm{C}$ for $30 \mathrm{~min}$ for enzyme inactivation and dried to a constant weight at $75{ }^{\circ} \mathrm{C}$ for $3 \mathrm{~d}$. The resulting dry weights were recorded. Then, the dried plant tissue was ground and digested for total $\mathrm{N}$ determination by using the Kjeldahl method. A 5-mL aliquot from a total of $100 \mathrm{~mL}$ per digested sample was analyzed using a continuous-flow autoanalyzer (FlowSys; Systea, Anagni, Italy).

\section{Measurement of root morphology}

Fresh roots were sampled at $7 \mathrm{~d}$ after $\mathrm{HN}$ and LN treatment and scanned on a flatbed scanner at 300 dpi. Root images were then analyzed on the LA-S Plant Root Analysis System (Wan Shen, Hangzhou, China). The root traits were described in terms of the total root length, main root length, root surface area, root volume, and root average diameter.

\section{Determination of root ${ }^{15} \mathrm{~N}$ influx and accumulation}

The Hua30 and A9-29 seedlings were grown in a nutrient solution containing $1.43 \mathrm{mM} \mathrm{NH}_{4} \mathrm{NO}_{3}$ for 3 weeks and then deprived of $\mathrm{N}$ for 1 week. The plants were transferred first to $0.1 \mathrm{mM} \mathrm{CaSO}_{4}$ for $1 \mathrm{~min}$ and then to a nutrient solution containing either 0.1 or $2.5 \mathrm{mM}{ }^{15} \mathrm{NH}_{4}{ }^{15} \mathrm{NO}_{3}$ (atom\% ${ }^{15} \mathrm{~N}$ : 99\%) for $5 \mathrm{~min}$ for root ${ }^{15} \mathrm{~N}$ influx and $7 \mathrm{~d}$ for ${ }^{15} \mathrm{~N}$ accumulation separately, and finally to $0.1 \mathrm{mM} \mathrm{CaSO}_{4}$ for $1 \mathrm{~min}$. Roots and shoots were separated immediately after the final transfer to $\mathrm{CaSO}_{4}$ and then frozen in liquid N. Samples were ground to a powder and dried to a constant weight at $75^{\circ} \mathrm{C}$. Ten milligrams of the powder from each sample was analyzed on the MAT253-Flash EA1112-MS system (Thermo Fisher Scientific, USA). ${ }^{15} \mathrm{~N}$ influx rate was then calculated using the method of Tang et al. (2012).

\section{RNA extraction, CDNA synthesis, and quantitative reverse transcription polymerase chain reaction (qRT-PCR)}

Total RNA was extracted from roots by using TRIzol reagent (Invitrogen) and treated with DNase I (Promega), according to the manufacturer's protocol. The quality of the extracted RNA was confirmed using a NanoDrop ND-1000 spectrophotometer. The cDNA synthesis of all RNA samples was performed using a PrimeScript II 1st Strand cDNA Synthesis kit (TaKaRa, Dalian, China) with $1 \mu \mathrm{g}$ of DNase-treated RNA, according to the manufacturer's protocol. The qRTPCR reaction mix consisted of $10 \mu \mathrm{L}$ of $2 \times$ PowerUp SYBR
Green Master Mix (Applied Biosystems, California, USA), $2.5 \mu \mathrm{L}$ of $10 \times$ diluted cDNA, and $1.6 \mu \mathrm{L}$ of $10 \mathrm{mM}$ stock solution of each primer to a final volume of $20 \mu \mathrm{L}$. Reactions were performed on 7500 Real-Time PCR System (Applied Biosystems) with the following conditions: $95^{\circ} \mathrm{C}$ for $10 \mathrm{~min}$, followed by 40 cycles of $95^{\circ} \mathrm{C}$ for $15 \mathrm{~s}, 60^{\circ} \mathrm{C}$ for $1 \mathrm{~min}$ to calculate cycle threshold $(\mathrm{Ct})$ values. After cycles, the melting curves were generated to verify the primers specificity. $H v G A P D H$ expression was used as a reference. The primers for HvNRT2.1, HvNRT2.5, HvNRT2.6, and HvNIAl were designed by primer 3 (http://primer3.ut.ee/). The other primers were derived from published articles. All the primers used in this study are listed in Supplementary Table S1. The qRT-PCR results were analyzed by the $2^{-\Delta \Delta \mathrm{Ct}}$ comparative method according to Livak and Schmittgen (2001) by using the following equation:

$$
\begin{aligned}
2^{-\Delta \Delta \mathrm{Ct}} & =2^{-[\Delta \mathrm{Ct}(\text { Treatment })-\Delta \mathrm{Ct}(\mathrm{Ck})]} \\
& =2^{-[\mathrm{Ct}(\text { Treatment })-\mathrm{Ct}(H v G A P D H)]-[\mathrm{Ct}(\mathrm{Ck})-\mathrm{Ct}(H v G A P D H)]}
\end{aligned}
$$

Three biological replicates were used to calculate the means and determine the statistically significant differences in each treatment.

\section{Statistical analysis}

Biomass, $\mathrm{N}$ content and concentration, and ${ }^{15} \mathrm{~N}$ influx rate and accumulation were analyzed statistically using the $\mathrm{t}$ -test in MS Excel 2007. A two-way analysis of variance (ANOVA) with least significant difference (LSD) multiple comparison test was conducted in gene expression on DPS (version 7.05; China). Graphs were plotted using OriginPro (version 8.0; OriginLab Corporation, USA).

\section{Results}

\section{Comparison of plant growth and $\mathrm{N}$ accumulation between Hua30 and A9-29 under HN and LN treatments}

Compared with $\mathrm{HN}$ treatment, $\mathrm{LN}$ treatment led to severely decreased shoots growth and elongated root length in Hua30 and A9-29. Moreover, Hua30 was more seriously inhibited than was A9-29. Furthermore, the oldest leaf showed chlorosis and withering earlier in Hua30 than in A9-29 under LN treatment (Supplementary Fig S1).

The biomasses of shoots and roots in Hua30 and A9-29 were weighed separately at the different time points under $\mathrm{HN}$ and $\mathrm{LN}$ treatments. Under $\mathrm{HN}$ treatment, shoot and root dry weights did not show significant differences between Hua30 and A9-29 at different time points (Fig. 1a and b). 
Fig. 1 Effect of high nitrogen $(\mathrm{HN})(\mathbf{a}, \mathbf{b})$ and low nitrogen (LN) (c, d) supply on dry weight of shoots $(\mathbf{a}, \mathbf{c})$ and roots $(\mathbf{b}, \mathbf{d})$ after $21 \mathrm{~d}$ treatment. Data are means \pm standard deviation (SD) of five biological replicates. * or ** indicated the significant difference $(P<0.05$ or $P<0.01$ ) between cultivars in same treatment
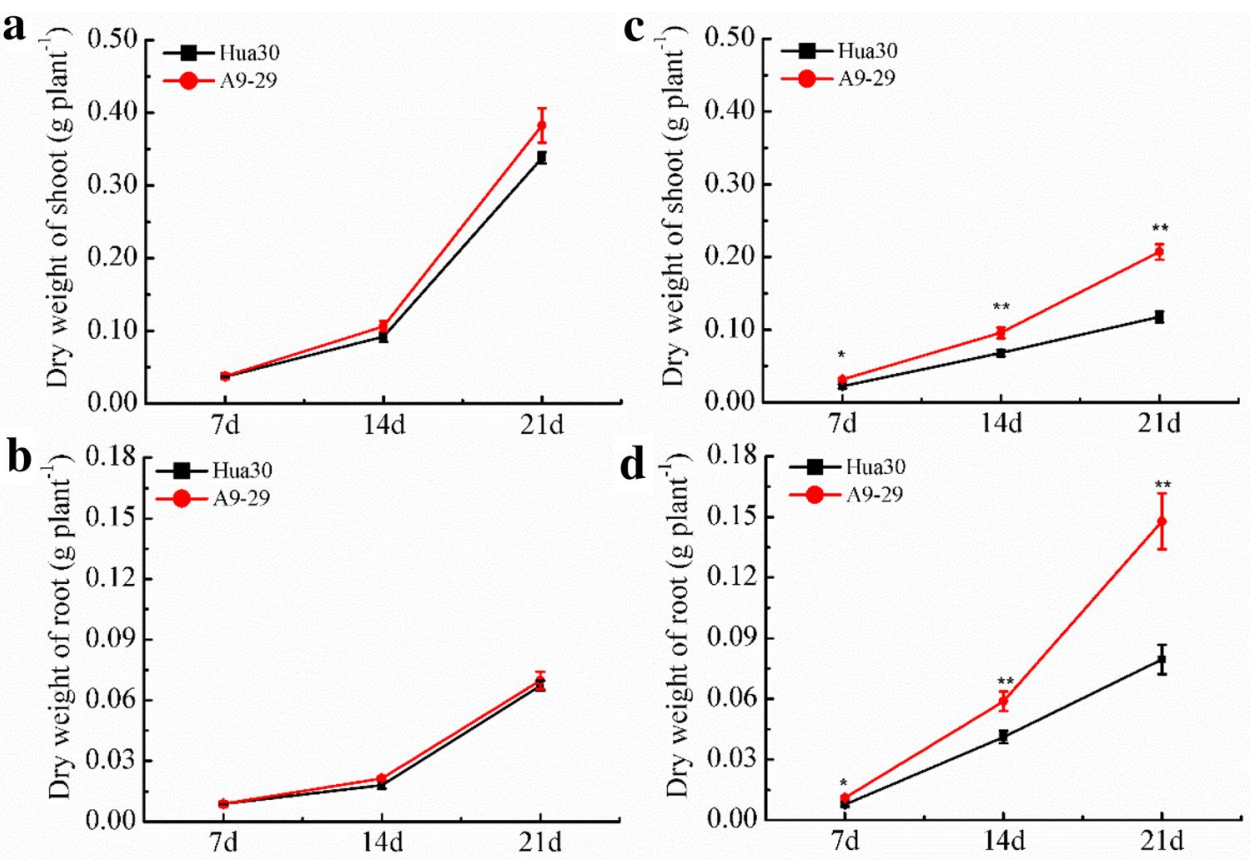

In contrast, under LN treatment, shoot and root dry weights increased more remarkably in A9-29 than in Hua30 at different time points (Fig. 1c and d).

The N contents of shoot and root in Hua30 and A9-29 were also measured. At 7 and $14 \mathrm{~d}$ of $\mathrm{HN}$ treatment, the differences in shoot and root $\mathrm{N}$ contents between Hua30 and A9-29 were nonsignificant. At 21d of HN treatment, root $\mathrm{N}$ contents were significantly higher in A9-29 than in Hua30 (Fig. 2a and b). LN treatment led to lower $\mathrm{N}$ contents than did HN treatment. In Hua30 and A9-29 under LN treatment, shoot $\mathrm{N}$ contents showed different trends compared with those in roots. In both Hua30 and A9-29, shoot $\mathrm{N}$ contents increased very slightly from 7 to $21 \mathrm{~d}$, whereas those in roots demonstrated a slight decrease from 7 to $14 \mathrm{~d}$, followed by an increase from 14 to $21 \mathrm{~d}$. In particular, under LN treatment, A9-29 showed significantly higher shoot $\mathrm{N}$ contents at different time points and
Fig. 2 Effect of HN (a, b) and LN (c, d) supply on nitrogen content of shoots $(\mathbf{a}, \mathbf{c})$ and roots $(\mathbf{b}, \mathbf{d})$ after $21 \mathrm{~d}$ treatment. Data are means \pm standard deviation (SD) of five biological replicates. $*$ or $* *$ indicated the significant difference $(P<0.05$ or $P<0.01$ ) between cultivars in same treatment
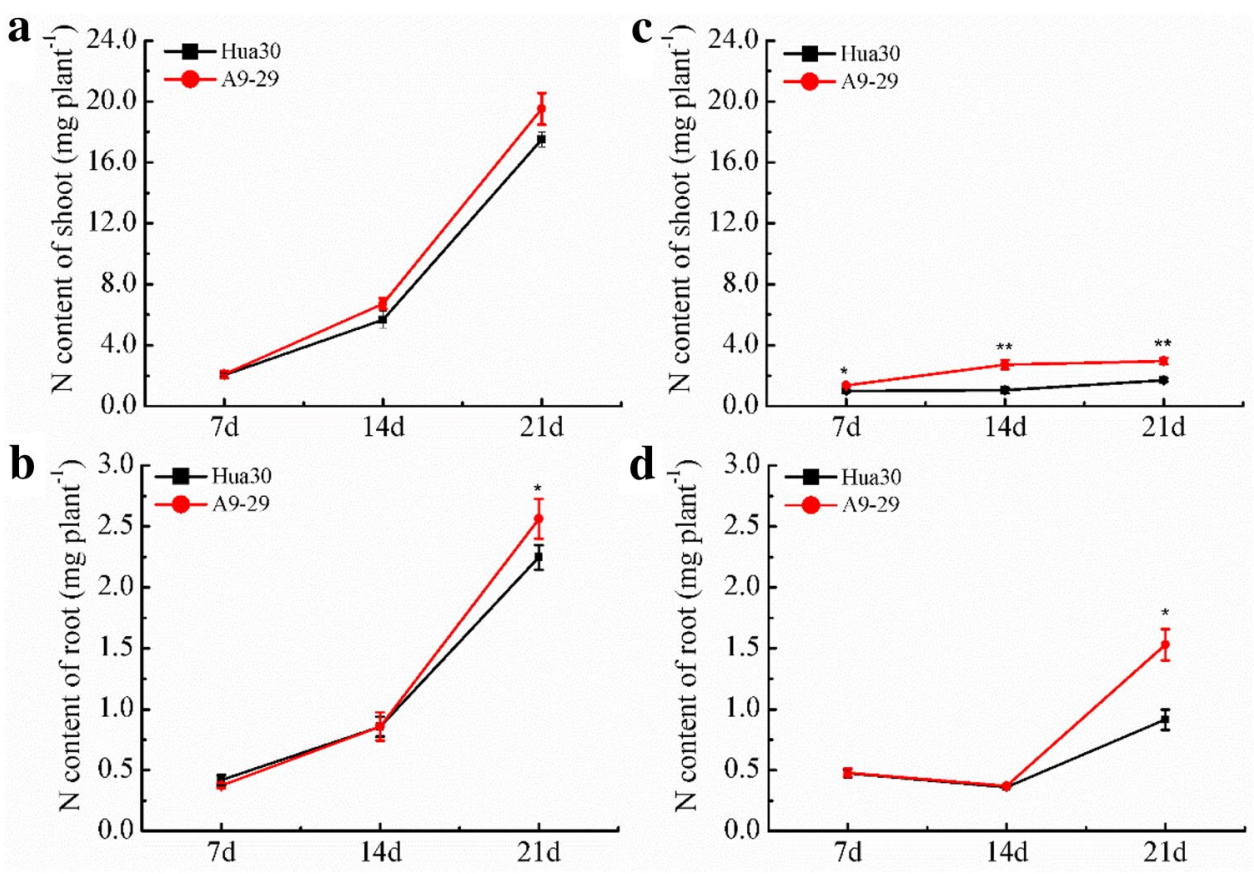
higher root $\mathrm{N}$ contents only at 21d than did Hua30 (Fig. 2c and d).

The $\mathrm{N}$ concentrations of shoot and root in Hua30 and A9-29 were analyzed further. The differences in shoot $\mathrm{N}$ concentrations at different time points or root $\mathrm{N}$ concentrations at $7 \mathrm{~d}$ between Hua30 and A9-29 under HN treatment were nonsignificant. Under $\mathrm{HN}$ treatment, root $\mathrm{N}$ concentrations were significantly higher at $14 \mathrm{~d}$ and then remarkably lower at 21d in Hua30 than in A9-29 (Supplementary Fig $\mathrm{S} 2 \mathrm{a}$ and $\mathrm{S} 2 \mathrm{~b}$ ). Under LN treatment, shoot $\mathrm{N}$ concentrations at $14 \mathrm{~d}$ was remarkably higher in A9-29 than in Hua30. In contrast, root $\mathrm{N}$ concentrations at 7 and $14 \mathrm{~d}$ were significantly higher in Hua30 than in A9-29 (Supplementary Fig $\mathrm{S} 2 \mathrm{c}$ and $\mathrm{S} 2 \mathrm{~d}$ ).

These results indicated that Hua30 and A9-29 had different responses to LN treatment. Under LN condition, A9-29 demonstrated better performance than did Hua30.

Table 1 Effect of HN and LN supply on root morphology between Hua30 and A9-29 on the 7th day of treatment

\begin{tabular}{llll}
\hline Root traits & Treatment & A9-29 & Hua30 \\
\hline Root length $(\mathrm{cm})$ & HN & $238.24 \pm 20.93 \mathrm{a}$ & $170.44 \pm 10.38 \mathrm{~b}$ \\
& LN & $360.70 \pm 12.65 \mathrm{a}$ & $240.17 \pm 13.31 \mathrm{~b}$ \\
Main root length $(\mathrm{cm})$ & $\mathrm{HN}$ & $20.25 \pm 1.12 \mathrm{a}$ & $14.69 \pm 0.52 \mathrm{~b}$ \\
& LN & $29.43 \pm 0.87 \mathrm{a}$ & $18.30 \pm 1.51 \mathrm{~b}$ \\
Root surface area & HN & $16.42 \pm 1.02 \mathrm{a}$ & $11.98 \pm 0.48 \mathrm{~b}$ \\
$\left(\mathrm{~cm}^{2}\right)$ & LN & $25.30 \pm 1.52 \mathrm{a}$ & $16.01 \pm 1.01 \mathrm{~b}$ \\
Root volume $\left(\mathrm{cm}^{3}\right)$ & $\mathrm{HN}$ & $0.14 \pm 0.01 \mathrm{a}$ & $0.11 \pm 0.01 \mathrm{~b}$ \\
& LN & $0.24 \pm 0.04 \mathrm{a}$ & $0.19 \pm 0.04 \mathrm{a}$ \\
Root average diam- & $\mathrm{HN}$ & $0.27 \pm 0.01 \mathrm{~b}$ & $0.33 \pm 0.01 \mathrm{a}$ \\
eter $(\mathrm{cm})$ & $\mathrm{LN}$ & $0.33 \pm 0.04 \mathrm{~b}$ & $0.49 \pm 0.05 \mathrm{a}$ \\
Root number & HN & $7.4 \pm 0.24 \mathrm{a}$ & $7.8 \pm 0.2 \mathrm{a}$ \\
& LN & $7.6 \pm 0.24 \mathrm{a}$ & $7.8 \pm 0.37 \mathrm{a}$ \\
\hline
\end{tabular}

Mean \pm SD $(n=5)$ with the same line followed the different letters

\section{Comparison of root morphology between Hua30 and A9-29 under $\mathrm{HN}$ and $\mathrm{LN}$ treatments}

Root dry weights were significantly higher in A9-29 than in Hua30 at different time points under LN treatment and the root system became more complex with LN treatment time prolongation. Therefore, we analyzed root morphology after $7 \mathrm{~d}$ of $\mathrm{HN}$ and $\mathrm{LN}$ treatments by using a root system scanner (Table 1). Compared with HN treatment, LN treatment enhanced root growth and elongation in Hua30 and A9-29. Root length, main root length, and root surface area were approximately $39.78 \%, 37.85 \%$, and $37.06 \%$ higher under $\mathrm{HN}$ treatment, respectively, and approximately $50.19 \%, 60.82 \%$, and $58.03 \%$ higher under LN treatment, respectively, in A9-29 than in Hua30. Under $\mathrm{HN}$ and $\mathrm{LN}$ treatments, root volume was approximately 27 and 21\% higher in A9-29 than in Hua30 respectively, with significant difference observed only under HN treatment. Moreover, root average diameter was approximately 22 and 48\% larger in Hua30 than in A9-29 under HN and LN treatments, respectively. Root number did not show significant difference between Hua30 and A9-29 under the two $\mathrm{N}$ treatments. These findings demonstrated that A9-29 had a greater absorption area to capture $\mathrm{N}$ nutrients and thus adapt to $\mathrm{N}$ deficiency.

\section{Comparison of $\mathrm{N}$ influx rate and accumulation between Hua30 and A9-29 on ${ }^{15} \mathrm{~N}$ resupply after $\mathrm{N}$ starvation}

To determine the root $\mathrm{N}$ influx and accumulation difference between Hua30 and A9-29, the short-term $\mathrm{N}$ uptake and long-term $\mathrm{N}$ accumulation were analyzed by exposing the $\mathrm{N}$-starved roots to 2.5 and $0.1 \mathrm{mM}{ }^{15} \mathrm{NH}_{4}{ }^{15} \mathrm{NO}_{3}$ for $5 \mathrm{~min}$ and $7 \mathrm{~d}$, respectively (Fig. 3). Compared with Hua30, A9-29 showed no differences in $\mathrm{N}$ influx rate at $2.5 \mathrm{mM} \mathrm{NH} \mathrm{NO}_{3}$, while a significantly higher $\mathrm{N}$ influx rate in roots was observed at $0.1 \mathrm{mM} \mathrm{NH}_{4} \mathrm{NO}_{3}$ (Fig. 3a). In the long-term treatments with both $2.5 \mathrm{mM}$ and $0.1 \mathrm{mM}$
Fig. $3 \mathrm{~N}$ influx rate (a) and $\mathrm{N}$ accumulation (b) in Hua30 and A9-29 at different concentration of ${ }^{15} \mathrm{NH}_{4}{ }^{15} \mathrm{NO}_{3}$. Data are means \pm standard deviation (SD) of three biological replicates. *indicated the significant difference $(P<0.05)$ between cultivars in same treatment a

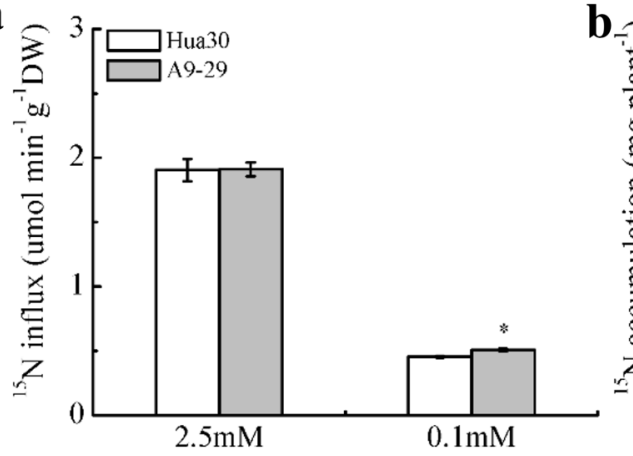

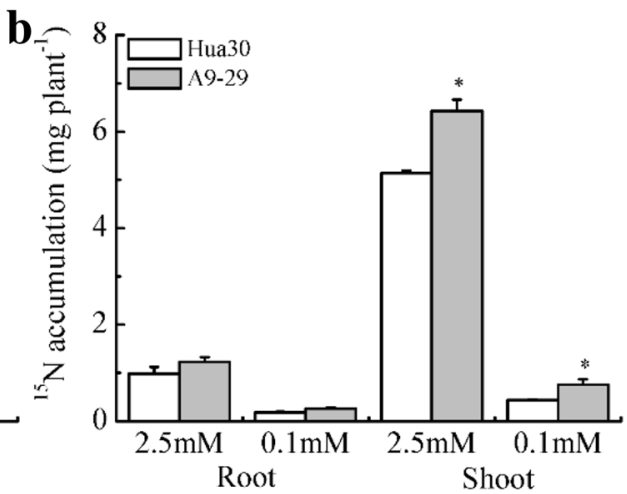


${ }^{15} \mathrm{NH}_{4}{ }^{15} \mathrm{NO}_{3},{ }^{15} \mathrm{~N}$ accumulation in shoots was significantly higher in A9-29 than in Hua30 (Fig. 3b).

\section{Comparison of root HvNRT expression levels between Hua30 and A9-29 under LN treatments}

The relative expression of five $H v N R T 2$ and two $H v N R T 3$ genes in Hua30 and A9-29 roots were analyzed at LN treatment. Two-way ANOVA showed that the expression levels of all genes showed significant differences between Hua30 and A9-29 $(P<0.05)$. The expression levels of all genes showed significant differences between the different time points $(P<0.05)$ and a significant interaction between barley lines and time points $(P<0.05)$ (Supplementary Table S2).

The expression of each gene was then compared between Hua30 and A9-29 separately (Fig. 4). In Hua30 $H v N R T 2.1$ expression increased significantly only at $21 \mathrm{~d}$ after LN treatment. Compared with Hua30, A9-29 showed significantly upregulated $H v N R T 2.1$ expression from 14 to $21 \mathrm{~d}$ after LN treatment (Fig. 4a). HvNRT2.2 and $H v N R T 2.3$ expression in the two materials demonstrated a similar pattern to that of HvNRT2.1. HvNRT2.2 expression in Hua30 showed nonsignificant differences during the treatment time points, whereas $H v N R T 2.2$ expression in A9-29 was obviously upregulated from 14 to $21 \mathrm{~d}$ and peaked at $14 \mathrm{~d}$ after LN treatment (Fig. 4b). HvNRT2.3 expression in Hua30 also showed nonsignificant difference during LN treatment, and $H v N R T 2.3$ expression in A9-29 was the identical to that of HvNRT2.1 and HvNRT2.2, which increased significantly from 14 to $21 \mathrm{~d}$ after $\mathrm{LN}$ treatment (Fig. 4c). HvNRT2.5 expression in Hua30 and A9-29 sharply increased at $7 \mathrm{~d}$ and then slightly decreased in Hua30 but persistently increased in A9-29 from 14 to $21 \mathrm{~d}$ and peaked at $14 \mathrm{~d}$ after $\mathrm{LN}$ treatment (Fig. 4d). The expression level of HvNRT2.6 was upregulated in Hua30 at $21 \mathrm{~d}$ and significantly enhanced in A9-29 from 14 to $21 \mathrm{~d}$ (Fig. 4e). HvNRT3.1 expression increased in two cultivars under LN treatment, with A9-29 showing a higher expression level from 14 to $21 \mathrm{~d}$ (Fig. 4f). HvNRT3.3 in both cultivars was upregulated from 3 to $21 \mathrm{~d}$, and in A9-29, it showed a higher expression from 14 to $21 \mathrm{~d}$ than in Hua30 (Fig. 4g).

These results indicated that long-term $\mathrm{LN}$ treatment enhanced the expression of $H v N R T s$, and these $H v N R T s-$ especially HvNRT2.1, HvNRT2.5, and HvNRT3.3—-showed a

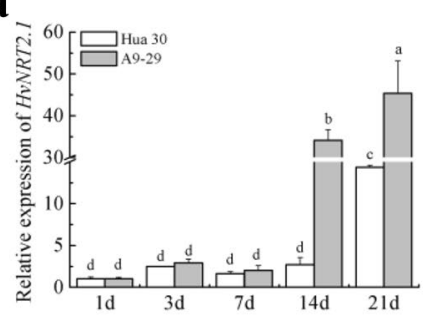

b

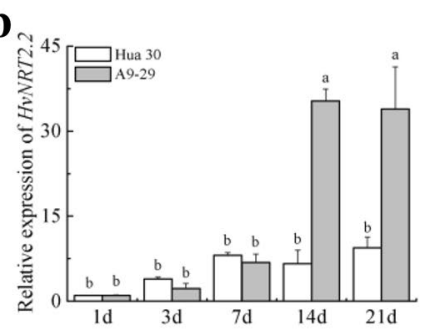

c

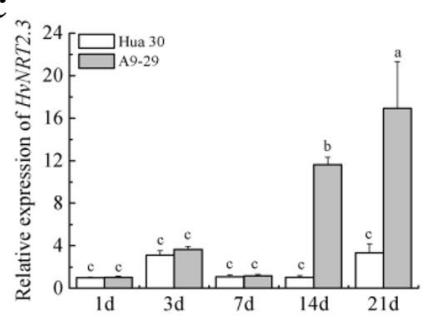

d
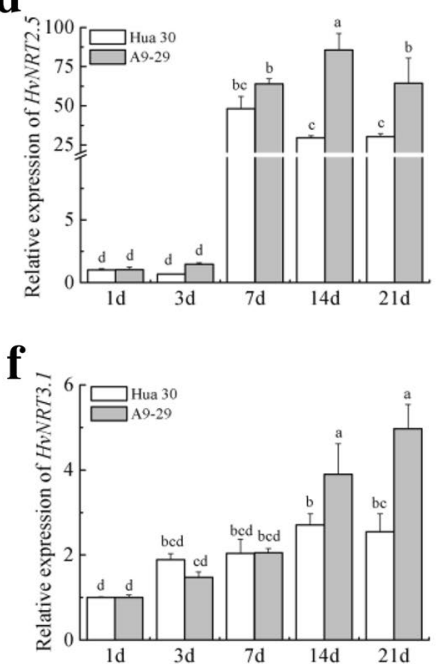

Fig. 4 Relative expressions of HvNRTs in roots between Hua30 and A9-29 under LN conditions. Data were means \pm standard deviation (SD) of three biological replicates. Error bars labels with different let- e
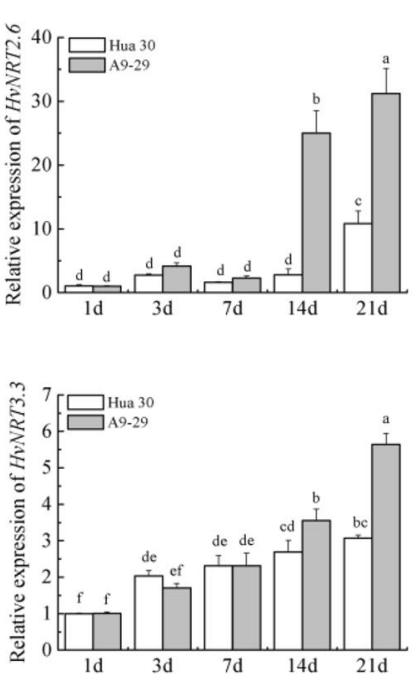

ters indicate significant differences $(P<0.05)$ between time and cultivars according to ANOVA, the same as below 
higher transcript levels in A9-29 than in Hua30 to improve $\mathrm{N}$ absorption.

\section{Comparison of root $\mathbf{N}$ assimilation gene expression between Hua30 and A9-29 under LN treatments}

The relative expression of eight genes involved in $\mathrm{N}$ assimilation were further investigated in Hua30 and A9-29 roots under LN treatment. Two-way ANOVA showed that the expression levels of all genes, except $H v G S 1 \_2, H v G S 1 \_4$, and $H v G S 1 \_5$, showed significant differences between Hua30 and A9-29 $(P<0.05)$. The expression levels of all genes showed significant differences between the different time points $(P<0.05)$. The expression levels of all genes, except HvGS1_2, HvGS1_4, HvGS1_5, and HvGLU2, showed significant interactions between the different barley lines and time points $(P<0.05)$ (Supplementary Table S3).

Subsequently, the expression of these genes was compared between Hua30 and A9-29 (Fig. 5). In Hua30, $H v N I A 1$ expression only slightly increased at $14 \mathrm{~d}$ after LN treatment, whereas that in A9-29 was significantly upregulated from 14 to $21 \mathrm{~d}$ (Fig. 5a). HvNIRI expression in Hua30 and A9-29 was obviously downregulated at 7d after LN treatment and then upregulated significantly from 14 to $21 \mathrm{~d}$ in A9-29, peaking at $14 \mathrm{~d}$ and was only upregulated at $21 \mathrm{~d}$ in Hua30 after LN treatment (Fig. 5b). HvGS1_l expression was upregulated in both the lines from 7 to $21 \mathrm{~d}$ and peaked at $14 \mathrm{~d}$ after LN treatment. However, A9-29 had significantly higher $H v G S 1_{-} 1$ expression from 14 to 21d than did Hua30 (Fig. 5c). HvGS1_3 expression was downregulated at $3 \mathrm{~d}$ in both the lines and then sharply upregulated from 7 to $21 \mathrm{~d}$ in A9-29, which increased from 7 to $14 \mathrm{~d}$ and then decreased at $21 \mathrm{~d}$ in Hua30 (Fig. 5e). $H v G S 1 \_2, H v G S 1 \_4$, and $H v G S 1 \_5$ expression levels showed slight differences between Hua30 and A9-29, which only increased from 3 to $14 \mathrm{~d}$ and then decreased at $21 \mathrm{~d}$ (Fig. 5d, f and g). HvGLU2 expression was upregulated only in A9-29 from 14 to $21 \mathrm{~d}$ (Fig. 5h). These results indicated that $\mathrm{LN}$ treatment enhanced $\mathrm{N}$ assimilation gene expression in A9-29. The higher transcript levels of HvNIA1, HvNIR1, HvGS1_1,HvGS1_3, and HvGLU2 $\mathbf{a}$
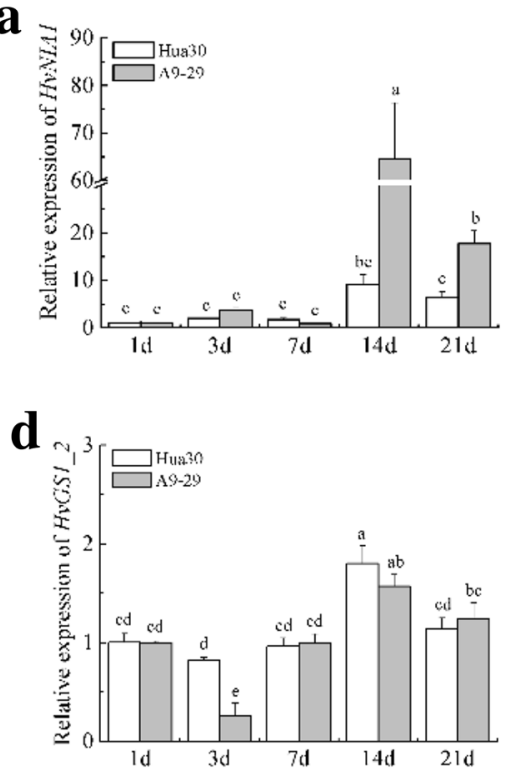

b

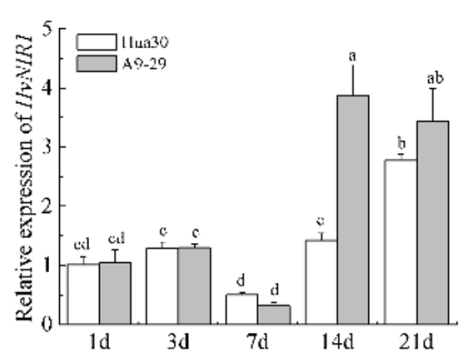

e

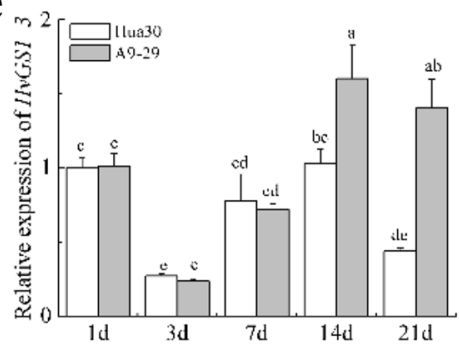

c

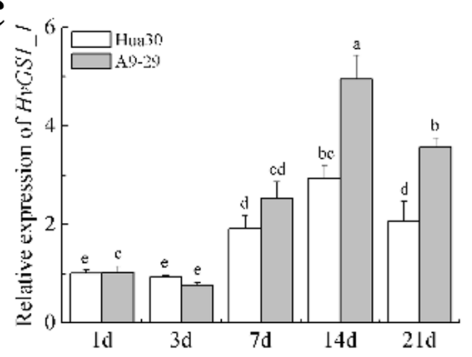

f

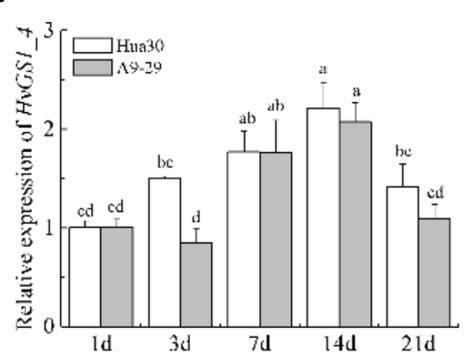

g

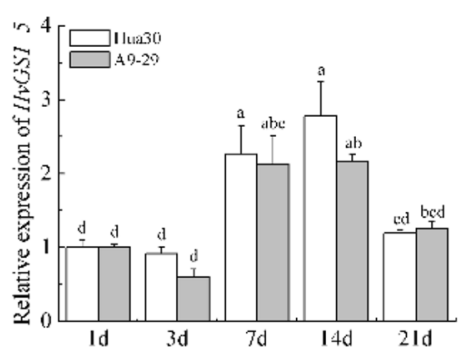

h

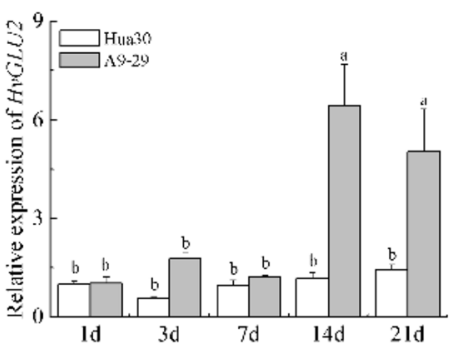

Fig. 5 Relative expressions of N assimilation genes in roots between Hua30 and A9-29 under LN conditions. Data were means \pm standard deviation (SD) of three biological replicates 
in A9-29 may play important roles in $\mathrm{N}$ assimilation in roots-which could further improve $\mathrm{N}$ absorption.

\section{Discussion}

Plant growth involves coordinated shoot and root development. A sufficient number of photosynthetic products generated in shoots is transferred to roots, which supports the development of root architecture and implementation of root function. Moreover, the larger the root biomass, the more is the biological yield (Duan 2019). N starvation severely affects plant growth, and high-NUE genotypes can generate more biomass and lead to higher $\mathrm{N}$ accumulation under LN stress (Liu et al. 2009; Xu et al. 2016). In this study, compared with the wild-type Hua30, A9-29 showed larger shoot and root biomass from 7 to $21 \mathrm{~d}$ under LN treatment (Fig. 1c and d), and higher $\mathrm{N}$ accumulation in both shoots and roots after long-term (21d) LN treatment (Fig. 2c and d). The lower root $\mathrm{N}$ concentration means more dry matter generated for A9-29 under LN treatment (Fig S2d). The difference in growth performance and $\mathrm{N}$ accumulation between the two barley genotypes indicated that A9-29 could maintain better growth than did Hua30 under LN treatment.

Nitrate is the most abundant $\mathrm{N}$ source (Miller et al. 2007). In addition to its role as a nutrient, nitrate can serve as a signaling molecule to modulate plant developmental processes, including root system architecture establishment (Krouk et al. 2010; O'Brien et al. 2016; Song et al. 2020). Under nitrate-limited conditions, plant roots employ an "active-foraging strategy" in response to nitrate deprivation by lateral root outgrowth and a shared pattern of transcriptome reprogramming (Ruffel et al. 2011). Root development is highly plastic and affected by various environmental factors (Forde 2014; Giehl et al. 2014). Nutrient availability has a widespread effect on the root system architecture by altering the numbers, length, angle and diameter of roots and root hairs (Gruber et al. 2013). An increase in root length under $\mathrm{N}$ deprivation might be related to the $\mathrm{N}$ deprivation-induced signaling cascade and the $\mathrm{N}$ foraging ability of the genotype (Gruber et al. 2013; Sinha et al. 2020). In this study, compared with Hua30, A9-29 had significantly increased main root length, total root length, and root surface area but decreased root average diameter under LN treatment. Moreover, the main root length only accounted for approximately $8 \%$ of the total root length (Table 1). These results indicated that larger root surface area in A9-29 was mainly attributable to higher lateral root length, thus resulting in an increased area for $\mathrm{N}$ absorption.

Plants have evolved two nitrate uptake systems, HATS and LATS, to cope with variable soil nitrate concentrations. NRT2.1 might be the main component of the HATS for root uptake under most conditions ( $\mathrm{Li}$ et al. 2007; O'Brien et al. 2016). In Arabidopsis, NRT2.1, NRT2.2, NRT2.4, and NRT2.5 primarily mediates nitrate uptake, with NRT2.1 being the major contributor (Plett et al. 2018). NRT2.2 partially compensates for when NRT2.1 is lost (Li et al. 2007). HvNRT2.1 in barley is vital in long-distance nitrate transport with low nitrate supply (Guo et al. 2020). In Arabidopsis, AtNRT2.3 and AtNRT2.6 both showed a constitutive expression pattern in the roots (Okamoto et al. 2003). OsNRT2.3b in rice is relatively stable in the roots and independent of the form and concentrations of the $\mathrm{N}$ supplied (Feng et al. 2011b). High OSNRT2.3b expression in rice enhances the pH-buffering capacity of the plant, thereby increasing $\mathrm{N}, \mathrm{Fe}$, and P uptake (Fan et al. 2016). AtNRT2.5 expression in Arabidopsis is induced under $\mathrm{N}$ starvation, and among the seven members of NRT2 family, AtNRT2.5 has the most abundant transcript levels in adult plants shoots and roots after long-term starvation (Lezhneva et al. 2014). OsNRT2.5 in rice-also known as $O s N R T 2.3 a$ - plays a role in the transport of nitrate from roots to shoots under low nitrate conditions (Tang et al. 2012). In wheat and maize, NRT2.5 has been found to be induced under LN stress (Garnett et al. 2013; Guo et al. 2014). HvNAR2.3 (HvNRT3.3) the most abundantly expressed in roots among the three $N A R 2$ family members in barley-is upregulated by nitrate and $\mathrm{N}$ starvation (Tong et al. 2005). In the current study, the expression of HvNRT2.1, HvNRT2.2, HvNRT2.3, and $H v N R T 2.6$ in A9-29 was markedly enhanced at 14 and 21 $\mathrm{d}$ of LN stress, whereas only HvNRT2.1 and HvNRT2.6 expression in Hua30 significantly increased at $21 \mathrm{~d}$ of LN stress (Fig. 4a, b, c and e). Of the aforementioned four genes, HvNRT2.1 was found to be expressed at the highest level, indicating that $H v N R T 2.1$ is predominant in nitrate uptake under LN conditions. HvNRT2.5 expression was also induced under $\mathrm{N}$ starvation and showed the highest transcript level among the HvNRT2 genes detected after $7 \mathrm{~d}$ of LN treatment (Fig. 4d). Although HvNRT3.1 and $H v N R T 3.3$ expression was upregulated under LN stress in Hua30 and A9-29, HvNRT3.3 was more sensitive in response to LN stress (Fig. 4f, g). Krapp et al. (2011) considered that long-term $\mathrm{N}$ starvation increases the highaffinity nitrate uptake capacity, and their transcriptome analysis revealed NRT2.4 and NRT2.5 to be candidates implicated in the uptake process. In this study, HvNRT2.4 expression levels were not measured because of unavailable specific primers to discriminate genes with high identity (95\%) of CDS between HvNRT2.4 (GenBank: AF091116.1) and HvNRT2.6 (GenBank: DQ539043.1). The higher HvNRT2.1, HvNRT2.5, and HvNRT3.3 expression levels in A9-29 on 14 and $21 \mathrm{~d}$ of LN treatment suggested that they play vital roles in $\mathrm{N}$ uptake, which may 
contribute to increased $\mathrm{N}$ uptake capacity in A9-29 in response to $\mathrm{LN}$ treatments.

In many plants, nitrate absorbed by roots is then assimilated in the roots and several enzymes, including NR, NiR, and GS, are involved in this process (Xu et al. 2012). NR is a highly regulated enzyme (Daniel-Vedele et al. 2010). In Arabidopsis, root NR activities might be well correlated with NIA1 transcript levels (Krapp et al. 2011). Compared with NR, only a single nitrite reductase, NiR1, was identified in barley (Ward et al. 1995). NiR is co-regulated with $\mathrm{NR}$ in response to $\mathrm{N}$ and $\mathrm{C}$ metabolites, at least at the transcriptional level (Meyer 2002). Moreover, NiR1 is a key target in the regulation of $\mathrm{N}$ assimilation and $\mathrm{NO}$ homeostasis and is relevant to the control of both plant growth and performance under stress conditions (Costa-Broseta et al. 2020). Cytosolic GS1 is important for primary $\mathrm{NH}^{+}$ assimilation in roots. GS1 isoforms are more abundant under LN treatment, and GS1 is more predominant than GS2 in barley (Avila-Ospina et al. 2015). GS1 also plays a key role in the maintenance of essential $\mathrm{N}$ flow and internal $\mathrm{N}$ sensing during the critical plant development stages (Thomsen et al. 2014). GLU2 encodes a ferredoxin-dependent glutamate synthase (Fd-GOGAT), which plays a major role in primary $\mathrm{N}$ assimilation in Arabidopsis roots (Coschigano et al. 1998). $\mathrm{LN}$ stress could result in increased $\mathrm{N}$ uptake rate and $\mathrm{N}$ accumulation in root cells, followed by the enhancement of the $\mathrm{N}$ assimilation ability. In contrast, increased $\mathrm{N}$ assimilation ability might be a feedback signal to promote $\mathrm{N}$ uptake under LN treatment (Jiang et al. 2017). In this study, large genotype-dependent differences were described in the expressional profile of the $\mathrm{N}$ assimilation genes that regulate $\mathrm{N}$ metabolism (Fig. 5). Compared with Hua30, A9-29 presented higher expression levels of $\mathrm{N}$ assimilation genes in roots, including HvNIAl, HvNIRI, HvGS1_l, HvGS1_3, and $\mathrm{HvGLU2}$ - which potentially contributed to the increased $\mathrm{N}$ uptake capacity in response to $\mathrm{LN}$ stress.

\section{Conclusions}

Plant growth, $\mathrm{N}$ accumulation, $\mathrm{N}$ influx rate, and potential gene expression were compared between the barley mutant line A9-29 and the barley wild-type Hua30 at the seedling stage. Compared with Hua30, A9-29 demonstrated increased $\mathrm{N}$ absorption area in root system architecture, higher root $\mathrm{N}$ influx and enhanced nitrate transport gene expression levels, all indicating a higher $\mathrm{N}$ uptake capacity. Moreover, increased $\mathrm{N}$ assimilation gene expression potentially promoted N absorption. Consequently, A9-29 demonstrated increased biomass and $\mathrm{N}$ accumulation in response to $\mathrm{LN}$ stress.
In conclusion, under long-term LN stress, the barley mutant line A9-29 absorbs $\mathrm{N}$ more efficiently than does its wild-type Hua30 at the seedling stage.

Supplementary Information The online version contains supplementary material available at https://doi.org/10.1007/s10725-021-00744-2.

Acknowledgements This work was supported by the National Natural Science Foundation of China (31801353), The Youth Talent Development Plan of Shanghai Municipal Agricultural System, China (Grant No. 20180133), Academic Specialty Development Project of Shanghai Academy of Agricultural Sciences (Grant No. 201907) and the earmarked fund for China Agriculture Research System (CARS-05-01A-02).

Author Contributions All authors contributed to the study conception and design. Plant growth, treatment and sample preparation were performed by RG and GG. The RNA samples were prepared by HX and YL. The qPCR experiments were performed by RG and ZC. Data collection and analysis were performed by GR and RL. The first draft of the manuscript was prepared by RG and edited by CL and JC. All authors commented on previous versions of the manuscript. All authors read and approved the final manuscript.

\section{Declarations}

Conflict of interest The authors declare that the research was conducted in the absence of any commercial or financial relationships that could be construed as a potential conflict of interest.

Open Access This article is licensed under a Creative Commons Attribution 4.0 International License, which permits use, sharing, adaptation, distribution and reproduction in any medium or format, as long as you give appropriate credit to the original author(s) and the source, provide a link to the Creative Commons licence, and indicate if changes were made. The images or other third party material in this article are included in the article's Creative Commons licence, unless indicated otherwise in a credit line to the material. If material is not included in the article's Creative Commons licence and your intended use is not permitted by statutory regulation or exceeds the permitted use, you will need to obtain permission directly from the copyright holder. To view a copy of this licence, visit http://creativecommons.org/licenses/by/4.0/.

\section{References}

Avila-Ospina L, Marmagne A, Talbotec J, Krupinska K, MasclauxDaubresse C (2015) The identification of new cytosolic glutamine synthetase and asparagine synthetase genes in barley (Hordeum vulgare L.), and their expression during leaf senescence. J Exp Bot 66(7):2013-2026. https://doi.org/10.1093/jxb/erv003

Beatty PH, Anbessa Y, Juskiw P, Carroll RT, Wang J, Good AG (2010) Nitrogen use efficiencies of spring barley grown under varying nitrogen conditions in the field and growth chamber. Ann Bot 105:1171-1182. https://doi.org/10.1093/aob/mcq025

Chen Z, Liu C, Wang Y, He T, Gao R, Xu H, Guo G, Li Y, Zhou L, Lu $\mathrm{R}$, Huang J (2018) Expression analysis of nitrogen metabolismrelated genes reveals differences in adaptation to low-nitrogen stress between two different barley cultivars at seedling stage. Int J Genomics. https://doi.org/10.1155/2018/8152860 
Coschigano KT, Melo-Oliveira R, Lim J, Coruzzi GM (1998) Arabidopsis $g l s$ mutants and distinct Fd-GOGAT genes:implications for photorespiration and primary nitrogen assimilation. Plant Cell 10(5):741-752. https://doi.org/10.1105/tpc.10.5.741

Costa-Broseta Á, Castillo MC, León J (2020) Nitrite reductase 1 is a target of nitric oxide-mediated post-translational modifications and controls nitrogen flux and growth in Arabidopsis. Inter J Mol Sci 21:7270. https://doi.org/10.3390/ijms21197270

Criado MV, Veliz CG, Roberts IN, Caputo C (2017) Phloem transport of amino acids is differentially altered by phosphorus deficiency according to the nitrogen availability in young barley plants. Plant Growth Regul 82:151-160. https://doi.org/10.1007/ s10725-017-0247-6

Daniel-Vedele F, Krapp A, Kaiser WM (2010) Cellular biology of nitrogen metabolism and signaling. In: Hell R, Mendel R-R (eds) Cell Biology of Metals and Nutrients. Springer, Berlin, pp 145-172

Davenport S, Le Lay P, Sanchez-Tamburrrino JP (2015) Nitrate metabolism in tobacco leaves overexpressing Arabidopsis nitrite reductase. Plant Physiol Bioch 97:96-107. https://doi.org/10. 1016/j.plaphy.2015.09.013

Duan P (2019) Response of maize genotypes with different nitrogen use efficiency to low nitrogen stresses. Acta Ecol Sin 39:77-80. https://doi.org/10.1016/j.chnaes.2018.05.005

Fan X, Naz M, Fan X, Xuan W, Miller AJ, Xu G (2017) Plant nitrate transporters: from gene function to application. J Exp Bot 68:2463-2475. https://doi.org/10.1093/jxb/erx011

Fan X, Tang Z, Tan Y, Zhang Y, Luo B, Yang M, Lian X, Shen Q, Miller AJ, Xu G (2016) Overexpression of a pH-sensitive nitrate transporter in rice increases crop yields. PNAS 113:7118-7123. https://doi.org/10.1073/pnas.1525184113

Feng H, Fan X, Yan M, Liu X, Miller AJ, Xu G (2011a) Multiple roles of nitrate transport accessory protein NAR2 in plants. Plant Signal Behav 6:1286-1289. https://doi.org/10.4161/psb.6. 9.16377

Feng H, Yan M, Fan X, Li B, Shen Q, Miller AJ, Xu G (2011b) Spatial expression and regulation of rice high-affinity nitrate transporters by nitrogen and carbon status. J Exp Bot 62:2319-2332. https:// doi.org/10.1093/jxb/erq403

Forde BG (2014) Nitrogen signalling pathways shaping root system architecture: an update. Curr Opin Plant Biol 21:30-36. https:// doi.org/10.1016/j.pbi.2014.06.004

Fu Y-F, Zhang Z-W, Yang X-Y, Wang Ch-Q, Lan T, Tang X-Y, Chen G-D, Zeng J, Yuan S (2020) Nitrate reductase is a key enzyme responsible for nitrogen-regulated auxin accumulation in Arabidopsis roots. Biochem Bioph Res Co 532(4):633-639. https://doi. org/10.1016/j.bbrc.2020.08.057

Gao R, Guo G, Fang C, Huang S, Chen J, Lu R, Huang J, Fan X, Liu C (2018) Rapid generation of barley mutant lines with high nitrogen uptake efficiency by microspore mutagenesis and field screening. Front Plant Sci 9:450. https://doi.org/10.3389/fpls.2018.00450

Garnett T, Conn V, Plett D, Conn S, Zanghellini J, Mackenzie N, Enju A, Francis K, Holtham L, Roessner U, Boughton B, Bacic A, Shirley N, Rafalski A, Dhugga K, Tester M, Kaiser BN (2013) The response of the maize nitrate transport system to nitrogen demand and supply across the lifecycle. New Phytol 198:82-94. https://doi.org/10.1111/nph.12166

Giehl RFH, Gruber BD, von Wirén N (2014) It's time to make changes: modulation of root system architecture by nutrient signals. J Exp Bot 65:769-778. https://doi.org/10.1093/jxb/ert421

Gojon A (2017) Nitrogen nutrition in plants: rapid progress and new challenges. J Exp Bot 68:2457-2462. https://doi.org/10.1093/jxb/ erx 171

Goodall AJ, Kumar P, Tobin AK (2013) Identification and expression analyses of cytosolic glutamine synthetase genes in barley
(Hordeum vulgare L.). Plant Cell Physiol 54:492-505. https://doi. org/10.1093/pcp/pct006

Gruber BD, Giehl RF, Friedel S, von Wirén N (2013) Plasticity of the arabidopsis root system under nutrient deficiencies. Plant Physiol 163:161-179. https://doi.org/10.1104/pp.113.218453

Guo B, Li Y, Wang S, Li D, Lv C, Xu R (2020) Characterization of the nitrate transporter gene family and functional identification of HvNRT2.1 in barley (Hordeum vulgare L.). PLOS ONE 15:e0232056. https://doi.org/10.1371/journal.pone.0232056

Guo Q, Love J, Roche J, Song J, Turnbull MH, Jameson PE (2017) A RootNav analysis of morphological changes in Brassica napus L. roots in response to different nitrogen forms. Plant Growth Regul 83:83-92. https://doi.org/10.1007/s10725-017-0285-0

Guo T, Xuan H, Yang Y, Wang L, Wei L, Wang Y, Kang G (2014) Transcription analysis of genes encoding the wheat root transporter NRT1 and NRT2 families during nitrogen starvation. J Plant Growth Regul 33:837-848. https://doi.org/10.1007/ s00344-014-9435-z

Han M, Wong J, Su T, Beatty PH, Good AG (2016) Identification of nitrogen use efficiency genes in Barley: searching for QTLs controlling complex physiological traits. Front Plant Sci 2016:01587. https://doi.org/10.3389/fpls.2016.01587

International Barley Genome Sequencing Consortium (2012) A physical genetic and functional sequence assembly of the barley genome. Nature 491:711-716. https://doi.org/10.1038/natur e11543

Iqbal A, Dong Q, Wang Z, Wang X, Gui H, Zhang H, Pang N, Zhang $\mathrm{X}$, Song M (2020) Growth and nitrogen metabolism are associated with nitrogen-use efficiency in cotton genotypes. Plant Physiol Bioch 149:61-74. https://doi.org/10.1016/j.plaphy.2020.02.002

Islam MS (2019) Sensing and uptake of nitrogen in rice plant: a molecular view. Rice Sci 26:343-355. https://doi.org/10.1016/j. rsci.2018.12.007

Jiang S, Sun J, Tian Z, Hu H, Michel EJS, Gao J, Jiang D, Cao W, Dai T (2017) Root extension and nitrate transporter up-regulation induced by nitrogen deficiency improves nitrogen status and plant growth at the seedling stage of winter wheat (Triticum aestivum L.). Environ Exp Bot 141:28-40. https://doi.org/10.1016/j.envex pbot.2017.06.006

Kiba T, Krapp A (2016) Plant nitrogen acquisition under low availability: regulation of uptake and root architecture. Plant Cell Physiol 57:707-714. https://doi.org/10.1093/pcp/pcw052

Krapp A, Berthomé R, Orsel M, Mercey-Boutet S, Yu A, Castaings L, Elftieh S, Major H, Renou J-P, Daniel-Vedele F (2011) Arabidopsis roots and shoots show distinct temporal adaptation patterns toward nitrogen starvation. Plant Physiol 157:1255-1282. https:// doi.org/10.1104/pp.111.179838

Krouk G, Crawford NM, Coruzzi GM, Tsay YF (2010) Nitrate signaling: adaptation to fluctuating environments. Curr Opin Plant Biol 13:266-273. https://doi.org/10.1016/j.pbi.2009.12.003

Lezhneva L, Kiba T, Feria-Bourrellier AB, Lafouge F, Boutet-Mercey S, Zoufan P, Sakakibara H, Daniel-Vedele F, Krapp A (2014) The Arabidopsis nitrate transporter NRT2.5 plays a role in nitrate acquisition and remobilization in nitrogen-starved plants. Plant J 80:230-241. https://doi.org/10.1111/tpj.12626

Li H, Hu B, Chu C (2017) Nitrogen use efficiency in crops: lessons from Arabidopsis and rice. J Exp Bot 68:2477-2488. https://doi. org/10.1093/jxb/erx101

Li W, Wang Y, Okamoto M, Crawford NM, Siddiqi MY, Glass ADM (2007) Dissection of the AtNRT2.1:AtNRT2.2 inducible highaffinity nitrate transporter gene cluster. Plant Physiol 143:425433. https://doi.org/10.1104/pp.106.091223

Liu J, Chen F, Olokhnuud C, Glass ADM, Tong Y, Zhang F, Mi G (2009) Root size and nitrogen-uptake activity in two maize (Zea mays) inbred lines differing in nitrogen-use efficiency. J Plant Nutr Soil Sci 172:230-236. https://doi.org/10.1002/jpln.200800028 
Livak KJ, Schmittgen TD (2001) Analysis of relative gene expression data using real-time quantitative PCR and the $2^{-\Delta \Delta C T}$ Method. Methods 25:402-408. https://doi.org/10.1006/meth.2001.1262

Meyer C (2002) Soluble and plasma membrane-bound enzymes involved in nitrate and nitrite metabolism. In: Foyer $\mathrm{CH}$, Noctor G (eds) Photosynthetic Nitrogen Assimilation and Associated Carbon and Respiratory Metabolism. Springer, Netherlands, pp 49-62

Miller AJ, Fan X, Orsel M, Smith SJ, Wells DM (2007) Nitrate transport and signalling. J Exp Bot 58:2297-2306. https://doi.org/10. 1093/jxb/erm066

Moll RH, Kamprath EJ, Jackson WA (1982) Analysis and interpretation of factors which contribute to efficiency of nitrogen utilization. Agron J 74:562-564. https://doi.org/10.2134/agronj1982.00021 962007400030037x

O’Brien JA, Vega A, Bouguyon E, Krouk G, Gojon A, Coruzzi G, Gutierrez RA (2016) Nitrate transport, sensing, and responses in plants. Mol Plant 9:837-856. https://doi.org/10.1016/j.molp. 2016.05.004

Okamoto M, Vidmar JJ, Glass ADM (2003) Regulation of NRT1 and NRT2 gene families of Arabidopsis thaliana: responses to nitrate provision. Plant Cell Physiol 44:304-317. https://doi.org/10.1093/ pcp/pcg036

Orsel M, Chopin F, Leleu O, Smith SJ, Krapp A, Daniel-Vedele F, Miller AJ (2006) Characterization of a two-component high-affinity nitrate uptake system in Arabidopsis. physiology and proteinprotein interaction. Plant Physiol 142:1304-1317. https://doi.org/ 10.1104/pp.106.085209

Plett DC, Holtham LR, Okamoto M, Garnett TP (2018) Nitrate uptake and its regulation in relation to improving nitrogen use efficiency in cereals. Semin Cell Dev Biol 74:97-104. https://doi.org/10. 1016/j.semcdb.2017.08.027

Quan X, Zeng J, Ye L, Chen G, Han Z, Shah JM, Zhang G (2016) Transcriptome profiling analysis for two Tibetan wild barley genotypes in responses to low nitrogen. BMC Plant Biol 16:30. https://doi. org/10.1186/s12870-016-0721-8

Raun WR, Johnson GV (1999) Improving nitrogen use efficiency for cereal production. Agron J 91(3):357-363. https://doi.org/10. 2134/agronj1999.00021962009100030001X

Ruffel S, Krouk G, Ristova D, Shasha D, Birnbaum KD, Coruzzi GM (2011) Nitrogen economics of root foraging: Transitive closure of the nitrate-cytokinin relay and distinct systemic signaling for $\mathrm{N}$ supply vs. demand. PNAS 108:18524-18529. https://doi.org/10. 1073/pnas.1108684108
Sinha SK, Kumar A, Tyagi A, Venkatesh K, Paul D, Singh NK, Mandal PK (2020) Root architecture traits variation and nitrate-influx responses in diverse wheat genotypes under different external nitrogen concentrations. Plant Physiol Bioch 148:246-259. https:// doi.org/10.1016/j.plaphy.2020.01.018

Song M, Fan X, Chen J, Qu H, Luo L, Xu G (2020) OsNAR2.1 interaction with OsNIT1 and OsNIT2 functions in root-growth responses to nitrate and ammonium. Plant Physiol 183:289-303. https://doi. org/10.1104/pp.19.01364

Tang Z, Fan X, Li Q, Feng H, Miller AJ, Shen Q, Xu G (2012) Knockdown of a rice stelar nitrate transporter alters long-distance translocation but not root influx. Plant Physiol 160:2052-2063. https:// doi.org/10.1104/pp.112.204461

Thomsen HC, Eriksson D, Møller IS, Schjoerring JK (2014) Cytosolic glutamine synthetase: a target for improvement of crop nitrogen use efficiency? Trends Plant Sci 19(10):1360-1385. https://doi. org/10.1016/j.tplants.2014.06.002

Tong Y, Zhou JJ, Li Z, Miller AJ (2005) A two-component high-affinity nitrate uptake system in barley. Plant J 41:442-450. https://doi. org/10.1111/j.1365-313X.2004.02310.x

Ward MR, Abberton MT, Forde BG, Sherman A, Thomas WTB, Wray JL (1995) The Nirl locus in barley is tightly linked to the nitrite reductase apoprotein gene Nii. Mol Gen Genet 247:579-582. https://doi.org/10.1007/BF00290349

Xu G, Fan X, Miller AJ (2012) Plant nitrogen assimilation and use efficiency. Annu Rev Plant Biol 63:153-182. https://doi.org/10. 1146/annurev-arplant-042811-105532

Xu H, Liu C, Lu R, Guo G, Chen Z, He T, Gao R, Li Y, Huang J (2016) The difference in responses to nitrogen deprivation and re-supply at seedling stage between two barley genotypes differing nitrogen use efficiency. Plant Growth Regul 79:119-126. https://doi.org/ 10.1007/s10725-015-0117-z

Yan M, Fan X, Feng H, Miller AJ, Shen Q, Xu G (2011) Rice OsNAR2.1 interacts with OsNRT2.1, OsNRT2.2 and OsNRT2.3a nitrate transporters to provide uptake over high and low concentration ranges. Plant Cell Environ 34:1360-1372. https://doi.org/10. 1111/j.1365-3040.2011.02335.x

Publisher's Note Springer Nature remains neutral with regard to jurisdictional claims in published maps and institutional affiliations. 